УДК 378.637

DOI 10.37386/2413-4481-2020-1-31-34

И.В. Федорова, О.Е. Рыбина

ОРГАНИЗАЦИЯ ПРЕДМЕТНОЙ ОЛИМПИАДЫ

ДЛЯ МЛАДШИХ ШКОЛЬНИКОВ

В ПРОФЕССИОНАЛЬНОЙ ПОДГОТОВКЕ БУДУЩИХ УЧИТЕЛЕЙ НАЧАЛЬНОЙ ШКОЛЫ

\begin{abstract}
В данной статье показывается значимость участия будущих педагогов начальной школы в организации и проведении предметной олимпиады для младших школьников. Раскрывая содержание каждого этапа предметной олимпиады, авторы обращают внимание на то, какие профессиональные умения и навыки приобретают студенты в ходе их реализации. Ключевые слова: предметная олимпиада, младшие школьники, профессиональная подготовка педагогов.
\end{abstract}

I.V. Fedorova, O.E. Rybina

\title{
ORGANIZATION OF THE SUBJECT OLYMPIAD FOR YOUNGER SCHOOLCHILDREN IN PROFESSIONAL TRAINING OF FUTURE TEACHERS OF ELEMENTARY SCHOOL
}

\begin{abstract}
This article shows the importance of the participation of future elementary school teachers in organizing and conducting the subject Olympiad for younger students. Describing the content of each stage of the subject Olympiad, the authors pay attention to professional skills students acquire in the course of their implementation.

Key words: subject Olympiad, elementary school students, professional training of teachers.
\end{abstract}

В профессиональной подготовке педагога начальных классов большое значение имеет компетентностный подход, заявленный в Федеральном государственном образовательном стандарте. Е.Г. Репина отмечает, что «существенная роль в образовательном процессе отводится самообразованию студентов, развитию креативности мышления для получения многовариантных решений профессиональных задач, способности эффективно действовать в условиях постоянно меняющейся внешней среды». Это обосновано спросом современного общества на высококвалифицированные кадры [1, с. 297].

Одним из средств реализации компетентностного подхода является организация предметных олимпиад для младших школьников. Согласно Федеральному закону «Об образовании в Российской Федерации» предметные олимпиады школьников проводятся для выявления и развития у обучающихся интеллектуальных и творческих способностей [2]. Они являются сплавом лучших традиций отечественного образования и инноваций; способствуют поддержанию единого образовательного пространства; играют роль сильного стимула для саморазвития личности и для стремления к самосо- вершенствованию и использованию своих потенциальных возможностей [3]. Олимпиада - ярчайшая составляющая отечественной системы образования, значение которой в формировании национальной интеллектуальной элиты страны повышается с каждым годом [4, с. 37].

Традиционно предметные олимпиады для младших школьников проводятся в основном на уровне районных и городских комитетов по образованию [5], задания для них разрабатываются учителями школ, методистами комитетов. Высшие учебные заведения редко организуют и проводят предметные олимпиады для младших школьников, что представляется нам не совсем целесообразным, так как любая олимпиада носит характер ранней профориентационной работы. Олимпиады же для школьников, которые проводят вузы, носят профессионально ориентированный характер, проводятся чаще всего с учениками средней и старшей школы $[6,7]$.

В ФГБОУ ВО «Алтайский государственный педагогический университет» (при поддержке комитета по образованию города Барнаула) с 2016 года проводится открытая городская олимпиада для младших школьников по русскому языку, ма- 
тематике, окружающему миру (далее - олимпиада). В ней принимают участие представители четвертых классов школ города Барнаула. Целями данной олимпиады являются:

- выявление и развитие у обучающихся творческих способностей и интереса к углубленному изучению общеобразовательных предметов;

- создание необходимых условий для поддержки одаренных детей;

- развитие у учащихся основ интеллектуальной деятельности;

- формирование универсальных учебных действий и умения интегрировать знания и применять их для решения нестандартных задач (Положение об Олимпиаде).

Олимпиада проходит в два дня и включает в себя:

- праздничное открытие олимпиады;

- выполнение олимпиадных заданий младшими школьниками;

- проведение мастер-классов и игр для учащихся, родителей и учителей;

- торжественное награждение победителей олимпиады.

Организаторами олимпиады являются преподаватели кафедры теории и методики начального образования и студенты, обучающиеся по направлению подготовки «Педагогическое образование (с двумя профилями подготовки)». Студенты в рамках курса по выбору «Организация внеучебной деятельности» знакомятся с такой формой организации внеурочной деятельности в начальной школе, как олимпиада. В ходе учебной практики (по получению первичных профессиональных умений и навыков, в том числе первичных умений и навыков научно-исследовательской деятельности) учатся организовывать и проводить городскую олимпиаду.

Это позволяет сформировать у студентов следующие компетенции:

Способность работать в команде, толерантно воспринимать социальные, культурные и личностные различия (ОК-5). Подготовка олимпиады происходит в малых группах, что дает возможность студентам научиться взаимодействовать друг с другом.

Готовность к профессиональной деятельности в соответствии с нормативно-правовыми актами сферы образования (ОПК-4). До олимпиады студенты знакомятся с нормативной базой ее проведения (Положение об олимпиаде).

Владение основами профессиональной этики и речевой культуры (ОПК-5). Овладение профессиональной этикой и соблюдение речевой культуры помогает студентам эффективно организовать не только взаимодействие между собой, но и с детьми, их родителями и учителями. Совместная работа с преподавателями кафедры позволяет быстрее овладеть профессиональными нормами.

Способность использовать современные методы и технологии обучения и диагностики (ПК-2). В рамках формирования этой компетенции акцент делается на использовании олимпиады как средства диагностики предметных результатов младших школьников. Особое значение в данном контексте приобретает обучение способам обработки и представления результатов олимпиады.

Готовность к взаимодействию с участниками образовательного процесса (ПК-6). В ходе проведения олимпиады студенты вступают во взаимодействие с учениками, родителями, учителями, учитывают их потребности и особенности $[8,9]$.

Таким образом, организация и проведение олимпиады позволяют комплексно подойти к профессиональной подготовке студентов. Работа студентов в рамках олимпиады осуществляется в несколько этапов:

- проектирование мероприятий открытия и закрытия олимпиады;

- разработка мастер-классов для учащихся, учителей и родителей, подбор подвижных игр;

создание олимпиадных заданий по предметам.

В рамках данных этапов студенты делятся на группы, каждая из которых отвечает за свою часть организации и проведения олимпиады. При этом все группы, независимо от выполнения своего конкретного задания, участвуют в общем обсуждении, представляют результаты своей работы на общих собраниях организаторов олимпиады.

Рассмотрим работу студентов на каждом из указанных ранее этапов организации олимпиады.

Целью этапа проектирования и дальнейшей реализации сценария открытия и закрытия олимпиады является воплощение творческих идей студентов для создания атмосферы праздника и значимости ежегодной олимпиады, сохранение традиций, погружение в мир знаний. Ежегодно в первый день мероприятия проходит торжественное открытие олимпиады, сценарий которого разрабатывают и реализуют студенты. Сложность данной работы состоит в том, что сценарий должен соответствовать общему направлению (олимпиада), быть максимально насыщенным, минимальным по времени, при этом нести общую идею мероприятия и не повторять уже существующие сценарии. Так, общей идеей первой олимпиады стал «рассказ» о детстве гениальных людей; вторая олимпиада основывалась на представлении российских детей-гениев; центральным звеном третьей олимпиады стали супергерои, спешащие на олимпиаду. 
Помимо открытия и закрытия олимпиады, во время которых общение с детьми и пришедшими с ними взрослыми было опосредованным, студенты разрабатывали мастер-классы и подбирали подвижные игры для непосредственной работы с ними.

Основные задачи данного этапа:

Подбор или разработка мастер-классов для детей, соответствующих таким требованиям, как минимальность затрат на материал, максимальная практическая значимость, физическая (не интеллектуальная) работа детей по изготовлению поделок, ограниченность по времени изготовления (не более 5-10 минут). Данные требования определяются тем, что мастер-классы для детей проводятся перед началом открытия олимпиады, не должны отвлекать детей от главного - решения олимпиадных заданий, при этом поделки должны привлечь внимание детей, чтобы они захотели пользоваться данным изделием, изготовить подобное дома.

Подбор или разработка мастер-классов для взрослых (родителей, учителей), соответствующих таким требованиям, как минимальность затрат на материал, физическая работа взрослых по изготовлению практичных и/или эстетически приятных поделок; занятость взрослых не менее чем на 60 минут. Эти требования связаны с тем, что взрослые мастер-классы проходят во время проведения основного этапа олимпиады (решение учащимися олимпиадных заданий); во время мастер-классов взрослые должны отдохнуть и получить полезный практический опыт оформления помещения или решения сложных ситуаций.

Подбор и проведение подвижных игр для детей с учетом требований: игры должны быть интересны учащимся четвертых классов, они не должны утомлять детей, в игре должен иметь возможность принять участие каждый ребенок независимо от его индивидуальных особенностей. Подвижные игры - это обязательный элемент олимпиады, т. к. они помогают, с одной стороны, «отвлечь» детей от ожидания начала олимпиады (перед открытием), с другой стороны, «задействовать» тех учащихся, которые выполнили олимпиадные задания раньше установленного времени.

Проведение мастер-классов для детей. Обязательное условие проведение любого мастер-класса это желание ребенка в нем участвовать, независимо от того, волнуется он перед началом олимпиады или нет. Поэтому от расположения мастер-класса, настроения его организаторов, их умения общаться с детьми, объяснять, помогать, зависит и то, насколько успешно пройдет эта часть мероприятия.

Проведение мастер-классов для взрослых. При организации мастер-классов для взросльх необходи- мо учитывать особенности тех категорий взрослых, которые приходят с детьми - учителя, родители, родственники. Психологически это сложные категории взрослых для работы со студентами, т. к. они воспринимают олимпиаду как соревнование, волнуются, стараются не вступать в общение с другими людьми.

Студенты, работавшие именно в рамках подготовки и проведения мастер-классов с детьми и взрослыми, а также подготовки и проведения подвижных игр с детьми, во всех трех олимпиадах отметили сложность и значимость этого этапа - и в плане подготовки, и при проведении: «нам пришлось познакомиться с различными техниками изготовления практически значимых поделок из подручных материалов»; «от того, как мы разработаем и организуем мастер-классы, зависел настрой детей на олимпиаду»; «мы играли с детьми, которые выходили до окончания олимпиады; ребята очень активные, мы играли не только в то, что было предложено мной, но и ученики сами предлагали интересные и увлекательные игры»; «я принимала участие в мастер-классе по изготовлению игрушекантистресс; дети с радостью создавали эти поделки своими руками, а затем уносили их с собой на олимпиаду»; «я готовила мастер-класс по изготовлению вазочек из лампочек; у нас в аудитории было очень много людей, и часть потом ушла на изготовление клумбочек из газет и салфеток»; «я волновалась, когда работала с родителями; но они так внимательно нас слушали и все делали; никто из них не вышел из аудитории без поделки».

Данный этап в организации и проведении олимпиады не менее важен с точки зрения профессиональной подготовки студентов, чем работа над сценарием или проектирование олимпиадных заданий, потому что позволяет иначе посмотреть на свои возможности и умения. Студенты не просто подбирали идеи для выполнения задания, они имели возможность проверить действенность своих разработок, увидеть достоинства и недостатки в собственной подготовке, оценить свое умение общаться с детьми и взрослыми, что приобретает важность в свете выбранной ими профессии педагога начальных классов.

Среди наиболее интересных мастер-классов в рамках всех трех олимпиад были выделены (с точки зрения студентов, учащихся и взрослых): мастерклассы по изготовлению закладок, пеналов из бумаги; игрушки-антистресс - для детей; мастер-классы по изготовлению вазочек из лампочек, букетов и клумб из газет и салфеток, рисование на пластиковых тарелках - для взрослых.

Целью этапа проектирования олимпиадных заданий стала разработка заданий по русскому языку, 
математике и окружающему миру с учетом знаний и умений учащихся четвертых классов и возможности их применения в нестандартной ситуации. Все задания разрабатывались после анализа выполнения олимпиадных заданий прошлого года, составления аналитического отчета по сложности и выполнимости заданий прошлых олимпиад, проработки основных требований к знаниям и умениям учащихся четвертых классов независимо от программы, по которой они обучались. Данный этап является сложным, в связи с различиями в программах для начальной школы, касающихся, в частности, разного объема изучаемого материала, включения разных терминов в учебники. Поэтому студенты совместно с преподавателями кафедры теории и методики начального образования ориентировались на общие положения курсов русского языка, математики и естествознания.

Работавшие в группах по созданию олимпиадных заданий студенты отмечают следующее: «в группе по разработке олимпиадных заданий по математике мы сначала сами прорешали рассматриваемый вариант заданий, обсудили моменты, которые показались нам трудными, определили уровни сложности заданий и критерии оценки заданий»; «при разработке олимпиадных заданий по русскому языку возникли некоторые трудности; они были вызваны отсутстви- ем опыта в данном виде работы»; «сложно было по русскому языку разрабатывать задания на одном тексте; те олимпиады, которые мы просматривали в интернете, включают в себя просто набор заданий, а у нас был один текст, и нужно было сделать задания из разных областей языка»; «окружающий мир - это то, что детям всегда интересно, они много о нем знают; но у нас была задача сделать какие-то такие задания, которые будут и интересными, и проблемными; над которыми дети будут думать, а не просто вспоминать то, что они изучили в школе».

Ориентированные на проблемные вопросы, возможность детей написать свое обоснованное мнение, применить свои знания при работе с более сложным материалом - олимпиадные задания по всем трем предметам позволили студентам не только реализовать свой интеллектуальный потенциал, но и подойти к работе ответственно, с осознанием того, что данные задания должны быть четкими, логичными, максимально понятными детям, доступными для обдумывания и решения.

Таким образом, организация и проведение предметной олимпиады для младших школьников на базе университета являются значимыми элементами профессиональной подготовки педагогов начальных классов, позволяют им практически подойти к решению ряда профессиональных задач.

\section{Библиографический список}

1. Репина Е. Г. Студенческое олимпиадное движение как инструмент поиска одаренной молодежи и педагогической работы с ней: принципы организации и опыт проведения // Самарский научный вестник. 2017. Т. 6, № 3 (20). С. 297-302.

2. Об образовании в Российской Федерации: Федеральный закон от 29.12.2012 № 273-Ф3 (ред. от 01.05.2019). URL: https://fzakon.ru (дата обращения: 05.09.2019).

3. Матиенко А. В. Опыт проведения всероссийской олимпиады школьников по иностранному языку в контексте интеграционных процессов в российском образовании // Magister Dixit. 2012. № 3. URL: https://cyberleninka. ru (дата обращения: 06.09.2019).

4. Вахитова Г. Х. Предметные олимпиады как способ повышения качества образования студентов педагогических вузов // Научно-педагогическое обозрение. 2013. № 1 (1). С. 36-39.

5. Николаева В. В., Соколова Е. И. Роль предметных олимпиад школьников в совершенствовании МСОКО // Научно-методическое обеспечение оценки качества образования. 2018. № 2 (5). С. 45-53.

6. Муравьев С. Е., Скрытный В. И. Олимпиады школьников // Высшее образование в России. 2017. № 6. C. $126-130$.

7. Зарипова 3. Ф. Региональная предметная олимпиада: практический опыт // Высшее образование в России. 2016. № 8-9. С. 136-141.

8. Об утверждении Федерального государственного образовательного стандарта высшего образования 44.03.05 «Педагогическое образование (с двумя профилями подготовки): Приказ Министерства образования и науки Российской Федерации от 09.02.2016 № 91. URL: https://fgos.ru (дата обращения: 05.09.2019).

9. Основная образовательная программа высшего образования по направлению 44.03 .05 «едагогическое образование (с двумя профилями подготовки)», профили подготовки: Начальное образование и Иностранный язык. URL: https: //www.altspu.ru (дата обращения: 05.09.2019). 